surface tension at $20^{\circ} \mathrm{C}$ by means of the new method are as good as those obtained by means of the previous methods 1,3. The advantages of the new method are that the surface tension at $20^{\circ} \mathrm{C}$ can be determined for hydrogenated as well as for non-hydrogenated mineral oil fractions by means of only one graph, using two, properly chosen, physical constants.

1. Cornelissen, J., Harva, O., and Waterman, H. I. Chimie \& Industrie. To be published.

2. Cornelissen, J., Harva, O., and Waterman, H. I. Erdöl \& Kohle. To be published.

3. Cornelissen, J. and Waterman, H. I. Constitution of mineral oil fractions. Development of a method to determine the carbon-type composition in a clear and simple way from the viscosity, the refractive index and the density, University Print, Delft, 1956.

4. Corneliasen, J. and Waterman, H. I. Chimie \& Industrie. To be published.

5. Cornelisen, J. and Waterman, H. I. Brennstoffchemie. To be published.

Received September 10, 1956.

\section{Die Verbreitung der Umbelliferose in der Pflanzenfamilie der Umbelliferen}

ANDERS. BERHEIM SVENDSEN

Pharmazeutisches Institut der Universität Oslo, Oslo-Blindern, Norwegen

Nach der Ermittelung der Konstitution 1 der Umbelliferose ${ }^{1}$ (2'- $\alpha$-D-galactopyranosyl-2- $\alpha$-D-glucopyranosyl- $\beta$ - D-fructofuranose) haben wir es von Interesse gefunden, zu untersuchen, ob das neue Trisaccharid, das wir früher in 3-4 verschiedenen Doldenpflanzen nachgewiesen haben ", ein allgemein vorkommender $\mathrm{Be}$ stendteil bei den Umbelliferen sei. Um diese Untersuchung durchführen zukönnen, haben wir Papierchromatographie benutzt. In einem Flüssigkeitsgemisch von Amylalkohol, Pyridin und Wasser ist es möglich, Trisaccharide - u.a. Raffinose und Umbelliferose - zu trennen. Die erwähnten Zucker passieren bei einer 20-24stündigen Durchlaufschromatographie (Whatman Filtrierpapier No. 1) etwa $8 \mathrm{~cm}$, beziehungsweise $10 \mathrm{~cm}$.
In einigen der unten beschriebenen Fälle wurde nur der obarirdische Teil der Pflanze, in den meisten Fällen aber wurden sowohl der unterirdische als der oberirdische Teil untersucht; in einigen Fällen wurden sogar Wurzel, Stengel, Blatt, Blumendolde und Dolde mit unreifen, grünen Früchten je für sich untersucht. In sämtlichen Fällen konnte die Umbelliferose in allen Teilen der Pflanze nachgewiesen werden. Die Menge schien von Art zu Art und von Pflanzenteil zu Pflanzenteil etwas zu variieren, ohne dass diese quantitative Frage vorläufig näher behandelt wurde. Neben der Umbelliferose haben wir in allen untersuchten Arten bedeutende Mengen von Saccharose und kleine Mengen von Monosacchariden gefunden. Bei den Untersuchungen wurde wegen der Gefehr eines enzymatischen Abbsus der Umbelliferose immer frisches Pflanzenmaterial nach Stabilisierung in kochendem Alkohol verwendet.

Nachstehend sind diə untersuchten Arten tabellarisch zusammengestellt. Sämtliche enthalten Umbelliferose.

Aegopodium podagraria L.

Aethusa cynapium L.

Angelica archangelica $\mathrm{L}$.

subsp. norvegica (Rupr.) Nordh.

subsp. litoralis (Fr.) Thell.

Angelica silvestris L.

Anthriscus silvestris (L.) Hoffm.

Carum carvi $\mathrm{L}$.

Chaerophyllum aromaticum $\mathrm{L}$.

Conium maculatum $\mathrm{L}$.

Heracleum sphondylium $\mathbf{L}$.

Imperatoria ostruthium L. Levisticum officinale Koch. Ligusticum scoticum L. Meum athamanticum Jacq. Myrrhis odorata (L.) Scop. Pimpinella major (L.) Huds. Pimpinella saxifraga $\mathrm{L}$.

Sium sisarum I.

Aufarbeitung des Pflanzenmaterials: $10-50 \mathrm{~g}$ frisches Pflanzenmaterial wurde mit 150$250 \mathrm{ml}$ Äthanol und $1 \longrightarrow 2 \mathrm{~g}$ Kalciumkarbonat in einem "Waring Blendor" 3 Minuten fein zerrieben, worauf das Gemisch sofort zum Sieden gebracht wurde. Das Pflanzenmaterial wurde nach Abkühlen abfiltriert und mit 20$30 \mathrm{ml}$ Wasser ausgewachsen. Die gesammelten Filtrate wurden dann während ein paar Minuten mit etwa $5 \mathrm{ml}$ gequollenem saurem Ionenaustauscher (Amberlite IR 120) und nach Filtrieren in der nämlichen Weise mit Amberlite IRA 400 geschüttelt. Das Filtrat wurde in 
einem heissen Luftstrom bis zu etwa $5 \mathrm{ml}$ eingeengt, durch eine Aluminiumoxydsäule (Aluminiumoxyd alkalifrei "Woelm"), $3 \mathrm{~cm} \times$ $\times 1,5 \mathrm{~cm}$, filtriert, die Säule mit $5 \mathrm{ml}$ Wasser ausgewaschen und das fast farblose Filtrat weiter, wie oben beschrieben, eingeengt.

Papierchromatographie: Aus dem isolierten Zuckergemisch wurden variierende Mengen für die papierchromatographischen Untersuchungen entnommen. Die Chromatogramme (Whatman Filtrierpapier No. 1 in Bogen $45 \times 18 \mathrm{~cm}$ ) wurden mit absteigender mobiler Flüsaigkeitsphase als 20-24-stündige Durchlaufschromatogramme entwickelt. Flüssigkeitsgemisch: Amylalkohol puriss. "Merck", Pyridin puriss. "Morck", Wasser, 7+7+6 Raumteile (einphasiges Gemisch). Als Vergleichssubstanzen wurden auf jedes Chromatogramm Umbelliferose, Raffinose und Saccharose appliziert. Sprühreagens: Eine gesättigte, wässerige Lösung von Harnstoff-Oxalat. Nach dem Besprühen des Chromatogramms wurde dies 5 Minuten auf $130-140^{\circ}$ im Trockenschrank erwärmt. Ketosehaltige Zucker ergeben grünschwarze Flecke.

Für ökonomische Unterstützung dieser Arbeit bin ich $A / S$ Norsk Varekrigsforsikrings Fond zu besonderem Dank verpflichtet.

1. Wickström, A. und Bærheim Svendsen, A. Acta Chem. Scand. 10 (1956) 1199.

2. Bærheim Svendsen, A. Zur Chemie norwegischer Umbelliferen (Diss.) Universität Oslo, Oslo 1954.

Eingegangen am 18. Oktober 1956.

The Electrostatic Model for Calculation of the Ligand Field Parameter of Octahedral Complexes

\author{
OLE BOSTRUP and \\ CHR. KLIXBOLL JøRGENSEN
}

Chemistry Departments $B$ and A, Technical University of Denmark, Copenhagen, Denmark

\begin{abstract}
Since 1951, several authors 1,2 have Sapplied the ligand field theory to the absorption spectra of octahedral complexes with partly filled d-shells and found very good agreement with the observed energy levels, provided that reasonable va. lues are chosen for the ligand field parameter $\triangle$ (also denoted by $\left(E_{1}-E_{2}\right)$ or $10 D q$ or
\end{abstract}

10 $\frac{10}{21} K$ ), the energy difference between the high $\gamma_{3}$-orbital and the low $\gamma_{5}$-orbital (containing at most four and six electrons, respectively). All the wovenumbers of the Laporte-forbidden bands can be expressed as multiples of $\Delta$ plus linear combinations of term distances, which seem ${ }^{3}$ to have somewhat smaller values for complexes than the corresponding gaseous ions.

When the observed values of $\triangle$ are compared, many regularities are conspicuous, which support the value of the treatment: For a given ligand, $\triangle$ increases with the oxidation state of the central ion and with the principal quantum number $3 d, 4 d$, and $5 d$. For a given central ion, Tsuchida's spectrochemical series can be expressed as increasing values of $\triangle$, depending mainly on the atom in the first coordination sphere:

$$
\mathrm{Br}<\mathrm{Cl}<\mathrm{F}<\mathrm{O}<\mathrm{N}<\mathrm{C}
$$

Ilse and Hartmann 4 applied an electro. static model to explain the absolute value of $\triangle$. Six point charges $q$, representing the ligands, perturb a hydrogen-like 3dwavefunction yielding an energy difference in atomic units between the two possible energy levels $\gamma_{3}$ and $\gamma_{5}$ :

$$
\begin{gathered}
\Delta \cong \frac{8}{27} q \cdot \frac{Z_{*}}{3} \cdot G_{4}\left(\frac{Z_{*}}{3} \cdot R\right) \\
\text { where } G_{4}(\mathrm{x}) \cong \frac{14175}{8 \mathrm{x}^{5}}
\end{gathered}
$$

where $Z_{*}$ is the effective charge acting on the hydrogen-like 3d-wavefunction and $R$ the distance between the centre of the metal ion and the point charge. However, the actual 3d-radial function cannot be hydrogen-like; e. g. in a nickel(II) ion, the potential near the nucleus must necessarily correspond to $Z=28$ and for large distances $r$ to $Z=3$, while $Z_{*}$ is some average value between these two limits. Recently, Hartree $^{5}$ calculated self-consistent field functions (with exchange) for gaseous ions which support this qualitative argument: When compared to a hydrogen-like function with the same average distance $r$ of the electron from the nucleus, Hartree's function is larger both for small values of $r$ (giving a smaller $r_{\max }$ ) and for large values of $r$ (vanishing more slowly, corresponding to the external charge plus one), while it is smaller for intermediate $r$. Thus, it will be more generally valid to write eqn. 2 in the more old-fashioned way, discussed by Belford ${ }^{6}$ : 